\title{
Improving the low solubility of resveratrol
}

\author{
Milica T Atanacković ${ }^{*}$, Ljiljana C Gojković-Bukarica², Jelena M Cvejić ${ }^{1}$ \\ From 18th Scientific Symposium of the Austrian Pharmacological Society (APHAR). Joint meeting with the \\ Croatian, Serbian and Slovenian Pharmacological Societies. \\ Graz, Austria. 20-21 September 2012
}

\section{Background}

Resveratrol, a polyphenol mainly present in grapes and red wine, demonstrated interesting biomedical properties for its cardioprotective action due to inhibition of the oxidation of low-density lipoprotein (LDL) and of platelet aggregation, inhibitory effects on cancer promotion and propagation and anti-inflammatory activities. These potential therapeutic and prophylactic applications are limited by the low bioavailability caused by its physical properties. Additionally, resveratrol has low water solubility and stability making its clinical success a formidable technological and medical challenge. The aim of this work is to present results of improvement of solubility of resveratrol through micellar and liposomal incorporation.

\section{Methods}

Solubilization of resveratrol in six different bile acid solutions (cholic acid and its keto derivates) was investigated after 18 hours of mixing $2 \mathrm{mg}$ of resveratrol in $2 \mathrm{ml}$ of bile acid solutions in $\mathrm{pH} 7$ buffer at room temperature. Liposome preparations containing pure resveratrol, resveratrol with vitamin $C$ and resveratrol with vitamin $E$ were prepared using the thin film hydration method. Resveratrol content was analyzed using HPLC with UV/DAD detection.

\section{Results}

The analysis of solubilization of resveratrol showed that keto derivatives of cholic acid have greater ability to solubilize resveratrol than cholic acid, and that this efficiency increases with the number of keto groups present in bile acid. The most effective acid for the solubilization of resveratrol was 3,7,12-triketocholic acid. Also, it has been shown that the efficiency of incorporation of resveratrol in liposomes increases with the amount of

\footnotetext{
* Correspondence: milica.at@hotmail.com

${ }^{1}$ Department of Pharmacy, Faculty of Medicine, 21000 Novi Sad, Serbia

Full list of author information is available at the end of the article
}

added resveratrol during preparation and the presence of vitamin $\mathrm{C}$ or $\mathrm{E}$ in the formulation, and that these preparations have satisfactory characteristics.

\section{Conclusions}

Experiments carried out in this study provide useful information for potential development of different dietary and pharmaceutical resveratrol products.

\section{Author details}

${ }^{1}$ Department of Pharmacy, Faculty of Medicine, 21000 Novi Sad, Serbia. ${ }^{2}$ Institute of Pharmacology, Clinical Pharmacology and Toxicology, Medical Faculty, University of Belgrade, 11129 Belgrade, Serbia.

Published: 17 September 2012

doi:10.1186/2050-6511-13-S1-A25

Cite this article as: Atanacković et al:: Improving the low solubility of resveratrol. BMC Pharmacology and Toxicology 2012 13(Suppl 1):A25.
Submit your next manuscript to BioMed Central and take full advantage of:

- Convenient online submission

- Thorough peer review

- No space constraints or color figure charges

- Immediate publication on acceptance

- Inclusion in PubMed, CAS, Scopus and Google Scholar

- Research which is freely available for redistribution

Submit your manuscript at www.biomedcentral.com/submit

\section{() Biomed Central}

C Biomed Central

(c) 2012 Atanacković et al; licensee BioMed Central Ltd. This is an Open Access article distributed under the terms of the Creative Commons Attribution License (http://creativecommons.org/licenses/by/2.0), which permits unrestricted use, distribution, and reproduction in any medium, provided the original work is properly cited. 